\title{
Kronik
}

\section{For en modificeret konkurrence på arbejdsmarkedet}

\author{
Henning Hansen, Jens Lind \& Iver Hornemann Møller
}

$\mathrm{L}$ iberalismen fejrer triumfer i disse år. Da troen på velfærdsstaten og keynesianismen begyndte at krakelere i 1970'erne, blev kapitalismens markedsgrundlag revitaliseret, og de gamle dyder og dogmer blev fundet frem og støvet af. Nu blev alt, hvad der hæmmede konkurrencens frie udfoldelse, betragtet som en fare for vækst og velfærd. Fagforeningernes indflydelse på løndannelsen skulle begrænses, velfærdsstaten moderniseres, og incitamentstrukturen skærpes gennem reduktion af de sociale standarder. Arbejdsløsheden blev igen betragtet som en naturlig del af økonomien, hvor det var den enkeltes eget valg, der var afgørende for, om man var arbejdsløs eller ej. Man kunne bare sænke sine lønkrav, så skulle man nok få et arbejde.

Da det liberalistiske paradigme for længst havde fundet solidt fodfæste, dukkede der overraskende nok et ekko fra en fjern fortid op. Flexicurity! Den danske arbejdsmarkedspolitik fra 1960'erne blev prototypen på den europæiske beskæftigelsespolitik og blev kaldt for flexicurity. I forlængelse af Maastricht-traktatens bestræbelser siden 1992 på at skabe konsensus mellem repræsentanterne for kapital og arbejde skulle der findes en model, som den europæiske beskæftigelsespolitik kunne udvikles over. Og efter styrkelsen af det indre marked og kanoniseringen af den frie bevægelighed for kapital, arbejde, varer og tjenester skulle der suppleres med en social dimension, som kunne fungere som et modtræk til de ulemper, det frie marked måtte medføre for lønmodtagerne.

Specielt fra slutningen af 1990'erne og frem til krisens gennemslag i 2008 fejrede flexicurity triumfer som en politisk ideologisk konstruktion til at finde en fælles referencemodel. Et modtræk eller et alternativ til liberalismens mest asociale konsekvenser.

Krisens tilbagerulning af velfærdsstatens sociale kompensationer har blotlagt en helt anden dagsorden for arbejdsmarkedspolitikken i Danmark og Europa. Det er det, der er temaet for denne kronik, hvor der startes med at omtale det nedskudte flagskib, flexicurity. Herefter fortsættes med en analyse af virksomhedernes ændrede konkurrencestrategi: Væk fra innovationer og produktivitet og mere vægt på lavere lønninger. Slutteligt skitseres et alternativ til det herskende paradigme for beskæftigelsespolitikken. Et alternativ, der bygger på de oprindelige hjørnestene i udformningen af det, der blev 
kaldt for aktiv arbejdsmarkedspolitik, men som i Danmark aldrig blev fuldt udviklet.

I argumentationen for en arbejdsmarkedspolitik med et menneskeligt ansigt vil vi undersøge teoretiske antagelser og principper for at indrette en sådan politik. Et væsentligt udgangspunkt vil her være, at konkurrencen og uligheden må begrænses. I et kapitalistisk samfund kan dette kun ske som en modifikation, men det er vores opfattelse, at de modsigelser og paradokser, som arbejdsmarkedspolitikken bygger på, netop udspringer af den ideologi, der anbefaler øget konkurrence og ulighed.

Teoretisk vil vi forholde os til udformningen af arbejdsmarkedspolitikken ud fra vækstteoretiske begreber (ekstensiv kontra intensiv kapitalakkumulation) og en grov dikotomisering af strategier i beskæftigelsespolitikken (liberalistisk kontra socialistisk), hvor vi argumenterer ud fra antagelser fra klassisk økonomisk teori, og hvor en væsentlig inspiration er hentet fra den såkaldte Rehn-Meidnermodel.

\section{Kapitalismen, arbejdssamfundet og forbrugssamfundet}

Kapitalismen, arbejdssamfundet og forbrugssamfundet er alle hver for sig meget konkrete, men også mangedimensionale størrelser, som gensidigt og på forskellig vis påvirker hinanden, men samtidigt i hver sin grundsubstans udtrykker noget specifikt. Fælles har de dog forudsætningen om, at en konsumentefterspørgsel er nødvendig for deres fortsatte eksistens.

Kapitalismen har til stadighed brug for forbrugernes nye og/eller større efterspørgsel for at kunne afsætte sine produkter.

I arbejdssamfundet hersker normen om, at alle arbejdsduelige personer i den produktive alder skal kunne 'forsørge sig og sine' og som en stiltiende forudsætning, at forbrugerne har ønsker om at efterspørge nye eller større mængder varer og tjenester, så indkomsterne fra arbejdet (og ekstraarbejdet) kan anvendes til at dække disse behov.

Lad os starte med kapitalismen. Den enkelte kapitalist skal ved blandt andet at holde lønningerne nede sikre sin egen profit og håber samtidigt på, at den samlede nationale og internationale efterspørgsel vil være stor nok til at sørge for afsætning af hans produkter. For de kapitalistiske nationalstater er den politiske opgave at sikre, at lønningerne ikke klemmer profitten så meget, at konkurrenceevnen trues, samtidigt med at lønningerne skal have en sådan højde, at det indenlandske forbrug kan bidrage væsentligt til at holde den nationale beskæftigelse og produktion i gang.

Arbejdsnormen, som gennem mange århundreder har domineret de vestlige landes holdning til arbejde, har udover sine bibelske rødder - Adam skulle efter Paradiset spise sit brød i sit ansigts sved - også sit calvinske afsæt, som senere blev forstærket af industrialiseringens protestantiske etik (Weber 1920). I de seneste årtier har arbejdsnormen gennem aktiveringspolitikken fået endnu en tand: "Der er brug for alle", "all hands on deck", "work, work, work", "arbetslinjen är vägen fram" osv. lyder det fra alle lande. Ledig kapacitet er ikke acceptabelt og ses som et ressourcespild.

I forbrugssamfundet kan befolkningen ikke få nok. Forbruget af varer og tjenester målt i både mængder og kvalitet svinger med konjunkturerne, men der er en langsigtet trend opad. I forbrugssamfundet måles individernes status især ved størrelsen og kvaliteten af deres forbrug (Bauman 2007), og de lavere klasser forsøger hele tiden både at forøge og tilpasse deres forbrug, så det mest muligt ligner de højere klassers. Både forbruget som statussættende og den enkeltes bestræbelser på at få sit forbrug til at ligne øvre klassers bidrager sammen med 
reklamer og aggressive markedsstrategier til at forstå, hvorfor nok aldrig bliver nok.

Artiklen tager afsæt i, at både kapitalismen, arbejdssamfundet og forbrugersamfundet forudsætter, at forbrugerne til stadighed søger at forøge deres efterspørgsel efter varer og tjenester, og at der i Danmark med en kapitalistisk domineret økonomi er en udtalt og af det store befolkningsmæssige og politiske flertal ukritisk opbakning til både arbejdssamfundet og forbrugssamfundet. Vi skal især fokusere på udviklingen mod virksomhedernes voksende konkurrence på lønnen og mindre på innovation, fornyelser og produktivitet. Vi ser også på forskellige typer af økonomisk-politiske foranstaltninger, som gennem samarbejde mellem kapital og arbejdskraft forsøger at sikre den nødvendige stigning i efterspørgslen, men samtidig også at balancere denne med en løntilbageholdenhed, som over for udlandet skal sikre en tilstrækkelig konkurrenceevne.

\section{Flexicuritymodellen}

Flexicurity er sammensat af begreberne 'flexibility' og 'security', hvor fleksibiliteten har til formål at sikre virksomhederne, at de kan få fat i, anvende og komme af med arbejdskraften i takt med deres behov, og hvor 'security' skal sikre arbejdskraften anstændige levevilkår i perioder med arbejdsløshed og løbende mulighed for tilpasning af sine kvalifikationer til virksomhedernes behov.

Begrebet er af hollandsk oprindelse fra slutningen af 1990'erne som en anden betegnelse for den arbejdsmarkedspolitik, der også var blevet kaldt for poldermodellen, fordi den virkede som et dige imod en liberalistisk og markedsstyret regulering af et arbejdsmarked med 'working poors'. På samme måde er begrebet i Danmark en betegnelse for det, der siden 1960'erne var blevet kaldt 'aktiv arbejdsmarkedspolitik', som igen var en - mindre ambitiøs - kopi af arbejdsmarkedspolitikken i den svenske såkaldte Rehn-Meidnermodel.

Så der var for så vidt ikke noget egentligt nyt i den såkaldte flexicuritymodel, men specielt efter 2000 og frem til omkring 2008 blev den berømmet for sine egenskaber til at sikre en stabil økonomisk og beskæftigelsesmæssig vækst. Specielt blev flexicurity og i særdeleshed den danske version fremhævet som en idealmodel for EU. Men også her var flexicurity faktisk bare en ny betegnelse for det, der siden starten af 1990'erne var blevet kaldt for European Employment Strategy (EES) (Larsson 1998).

Begrundelsen for populariteten i EU var den samme som i Holland og Danmark (og til en vis grad også i Østrig og Irland i 1990'erne), nemlig at den tilsyneladende var et socialt afbalanceret alternativ til USA's liberalistiske regulering. Ideologiskpolitisk var modellen yderst velegnet, idet den tog hensyn til arbejdsgivernes ønsker om fleksibilitet og arbejdernes ønsker om social tryghed. Dermed var den det ideelle fælles projekt for samarbejdet mellem kapital og arbejde: Flexicurity delte sol og vind lige, og man havde en fælles platform at argumentere ud fra.

Dette tilsyneladende sammenfald af interesser mellem repræsentanterne for kapital og arbejde kom i denne periode frem til krisens gennemslag i 2008 oftest til syne som en slet skjult stolthed over, at denne danske model var en model for hele Europa. Og ikke mindst var det tydeligt, at både arbejdsgivere og fagforeninger sammen med den liberalistiske regering og oppositionen i perioden berømmede modellen og dens økonomiske og beskæftigelsesmæssige potentiale. Som den daværende liberalistiske finansminister udtrykte det ved flexicuritykonferencen 'Pathways towards a better combination of flexibility and security' i Bruxelles, april 2007: 
"An effective social security safety net ensures that unemployed people will not have to leave their homes because of an abrupt loss of income. Our active labour market policy ensures that the unemployed are offered retraining for new jobs if their old jobs cease to exist. The safety net is part of the Danish flexicurity model. The model combines substantial public benefits with a labour market in which it is easy to hire and fire people. Workers get security and employers get freedom of action" (Beskæftigelsesministeriet).

Flexicuritymodellens væsentligste elementer er en høj kompensation $i$ form af dagpenge eller kontanthjælp i tilfælde af arbejdsløshed, en omfattende uddannelse og kvalificering af arbejdsstyrken kombineret med skrappe rådighedsregler og aktiveringsforanstaltninger for de arbejdsløse og lille ansættelsestryghed i form af korte opsigelsesvarsler for de beskæftigede.

Dagpengenes højde blev ved lovrevisionen i 1960 'erne og starten af 1970'erne fastlagt som et generelt maksimum på $90 \%$ af gennemsnitslønnen og et individuelt maksimum på $90 \%$ af tidligere indtægt. Den gennemsnitlige kompensationsgrad for en LO-arbejder var i starten af 1980'erne omkring $75 \%$, men efter 20 års ændringer af beregningsgrundlaget og beregningen af den maksimale dagpengesats (blandt andet et fradrag på $0,3 \%$ i satsreguleringsprocenten til den såkaldte satsreguleringspulje) var denne kompensationsgrad faldet til $55 \%$ i midten af 00'erne og er siden sænket yderligere (LO 2006). Dagpengeperioden blev i samme tidsrum sænket fra i princippet uendelig - hvis den arbejdsløse benyttede sig af retten til aktivering, hvor dagpengeretten kunne genoptjenes på seks måneder - til to år i 2011. Genoptjeningsperioden blev i 00'erne hævet fra seks måneder til et år, og rådighedsreglerne er blevet skærpet.
Dertil kommer, at aktiveringen af arbejdsløse er ændret fra som i 1980'erne at skulle genoptræne og uddanne langtidsarbejdsløse til at skulle fremme motivationen hos den arbejdsløse til selv at finde et arbejde.

Alt i alt har nedskæringerne i arbejdsløshedslovgivningen ændret sig fra at skulle kompensere den arbejdsløse for en arbejdsløshed, som i overvejende grad er samfundsbetinget, til at skulle forøge incitamentet hos den enkelte til at finde et job (Møller m.fl. 2008). Trygheden er blevet væsentligt forringet, og i stigende grad siden starten af 1980 'erne er perioder med arbejdsløshed ensbetydende med markante forringelser af levestandarden.

\section{Hvorfor blev flexicurity til en død sild?}

På denne baggrund kan der argumenteres for, at flexicurity var delvis effektiv i 1980'erne, hvor kompensationen var omkring $75 \%$, men at det efterfølgende gradvise fald i dækningen betød, at begrebet faktisk havde udspillet sin rolle allerede, da det som nævnt blev relanceret i løbet 1990'erne. Når arbejdsstyrken i dag stadigvæk er meget fleksibel, skyldes det ikke en høj grad af tryghed, men en høj grad af utryghed. Lønarbejdere må i stigende grad tilpasse sig de betingelser, der bliver udstukket af arbejdsgiverne.

Der er også blevet peget på, at en anden svaghed ved flexicurity er, at når cirka en fjerdedel af den danske arbejdsstyrke ikke er forsikret mod arbejdsløshed og derfor ikke er med i systemet, men må nøjes med den noget lavere kontanthjælp, er ordningen via øget numerisk fleksibilitet tendentielt med til at øge udstødningen af den mindst effektive arbejdskraft. Flexicurity indeholder heller ikke incitamenter for virksomhederne til fx i form af oplæring, uddannelse og anden virksomhedstræning at 
integrere de mest arbejdsmarkedsmarginaliserede, herunder især immigrantarbejdskraften (Hansen 2007). Der er dog grund til at tvivle på, at disse svagheder - udover dækningsgraden ved arbejdsløshed - har spillet nogen større rolle for, at flexicurity fra at være et stærkt hyldet og opblæst system er blevet en død sild.

Udover den lave dækningsgrad synes andre forklaringsbidrag nemlig at presse sig på. Med den internationale krises gennemslag i Vesteuropa i 2008/2009 blev det tydeligt, at nogle lande klarede sig bedre end andre. Og blandt de lande, for hvem det gik dårligst, var Danmark. Hverken hvad angår vækst, beskæftigelse eller arbejdsløshed, var der noget at vise frem, og den danske eksponering af flexicurity ophørte.

Som nævnt bygger flexicurity på samarbejde mellem kapital, arbejde og stat. Først og fremmest gennem den danske model med aftaler mellem fagforeningerne og arbejdsgiverne samt via statslige indsatser til kvalificering og uddannelse af arbejdskraften - ofte udformet gennem aftaler mellem fagforeningerne og arbejdsgiverorganisationerne. Men samarbejdsideologien kom i stigende grad på kant med den - siden 1980'ernes begyndelse - stadigt mere dominerende liberalistiske ideologi, som i voksende omfang udformer store dele af arbejdsmarkedspolitikken og socialpolitikken, og som for den økonomiske politiks vedkommende er karakteriseret ved en bevægelse fra keynesianisme til monetarisme. Den liberalistiske ideologi indebærer blandt andet, at markedet skal være den centrale fordelingsmekanisme, og at enhver forhindring for markedets frie udfoldelse, herunder også formelle og uformelle aftaler mellem arbejdsmarkedets parter og staten, er et onde. Også liberalismens fremhævelse af det enkelte individs ansvar for sig selv og sin familie og af statens beskedne rolle i samfundet passer dårligt med flexicuritys forudsætning om samarbejde mellem stat, kapital og arbejde.

\section{Mod øget løntrykkeri}

Det har formentlig også været af betydning for det officielle Danmarks uformelle aflivning af flexicuritymodellen, at mange danske virksomheder ikke har kunnet eller ikke har villet udnytte den del af flexicuritytankegangen, som åbner for, at arbejdskraftens høje fleksibilitet udnyttes til organisatoriske og teknologiske fremskridt. En del tyder på, at frem for at skabe profit gennem organisatoriske, tekniske og innovative forbedringer har mange virksomheder i det sidste årti i stigende grad lagt mere vægt på at sikre indtjening via lave lønninger.

Produktivitetskommissionen (2014) viser, at produktiviteten især halter i de private servicebrancher, der er rettet mod hjemmemarkedet, og at dynamikken er svagest i de servicebrancher, der primært er orienteret mod det danske marked og ikke udsat for international konkurrence. Den svage dynamik tyder på, siger kommissionen videre, at markedskræfterne ikke i tilstrækkelig grad tilskynder virksomhederne til at effektivisere og være innovative - og at konkurrencen ikke er stærk nok til at sikre, at de mest produktive virksomheder vinder hurtigt frem. For Industriens vedkommende har produktivitetstilvæksten de senere år derimod været på linje med de bedste i Europa, men under USA's. Og kommissionen fortsætter:

"Den svage vaekst tyder på, at markedskraefterne ikke i tilstraekkelig grad tilskynder virksomhederne til at effektivisere og innovere[...]" (Ibid., 14).

Kommissionen peger videre på, at danske produktions- og servicevirksomheder $\mathrm{i}$ sammenligning med de fleste andre vest- 
lige lande i væsentlig mindre grad beskæftiger (højt) kvalificeret arbejdskraft, og at uddannelserne i Danmark generelt lader en del tilbage at ønske i forhold til virksomhedernes krav.

Kapitalister og virksomhedsledere har da også traditionelt argumenteret for løntilbageholdenhed og i krisetider ligefrem for lønnedgang. Siden den økonomiske krise fra 2008 er fagforeningerne ved overenskomstforhandlingerne blevet mødt med krav om så megen løntilbageholdenhed, at der i realiteten har været krav om reallønsnedgang (Kongshøj Madsen 2011). Og på de enkelte virksomheder er lønarbejderne i dagens Danmark ikke sjældent blevet stillet over for valget mellem at gå ned i løn eller få lukket (dele af) virksomheden. Danish Crown og SAS er blandt de nyere eksempler.

I stedet for at udnytte flexicuritymodellens incitament til produktivitetsforbedringer, som beskæftigelsesministeren i ovenstående tekst ganske rigtigt pegede på, ser det ud til, at alt for mange danske virksomheder har satset på, at holde lønningerne nede. De søger at skabe profit ikke via produktivitetsforbedringer og innovation, men ved at ansætte mere lavtlønnet arbejdskraft.

I den primære sektor, landbrug og gartneri, mærkes det lavere kapitalafkast tydeligt, og der sker en voksende import af lavtlønnet udenlandsk arbejdskraft. Samme udvikling med stigende vægt på lavere lønninger ses også i byggesektoren - ligeledes med import af lavtlønnet udenlandsk arbejdskraft som et konkret udtryk herfor. Også inden for industrien mærkes den reducerede indtjening. Selvom der er sket en udvikling, hvor industribeskæftigelsen siden krisens gennemslag i 2008 er gået tilbage med ca. 20 \% (ca. 85.000) beskæftigede, og produktiviteten, som nævnt, er på højde med de bedste lande i Europa, men under USA's (Produktivitetskommissionen 2014), synes mange industrivirksomheder nu at satse mere på lave lønninger. Både i de primære og i de sekundære erhverv har der inden for de seneste årtier foregået en betydelig strukturtilpasning med fokus på lønnen som den vigtigste konkurrenceparameter. Og hvor lavtlønnet arbejdskraft ikke kan skaffes i Danmark eller fra udlandet eller via sort arbejde, vil virksomhederne eller dele heraf flytte til lande, hvor arbejdskraft med samme kvalifikationer kan købes billigere. Virksomhedernes voksende satsning på lave lønninger som vejen til profit indebærer således også outsourcing af produktionen. Det er eksempelvis ikke svært at forstå, at når lønudviklingen i Tyskland på det nærmeste er gået i stå de sidste cirka 10 år (AE Rådet 2013), foretrækker mange danske svineproducenter at få deres svin slagtet $i$ Tyskland frem for Danmark, hvor de årlige lønstigninger i tilsvarende periode har været på cirka $2 \%$.

Lastbilstransporten er et eksempel fra servicesektoren på, at der satses på billig udenlandsk arbejdskraft. Ved at flytte danske transportfirmaer til udlandet kan der indgås aftaler med lavtlønnede udenlandske chauffører, og ved nøje logistisk tilrettelæggelse af transporten kan de eksisterende aftaler om deres begrænsede adgang til transport i Danmark omgås. Andre eksempler er danske virksomheder, der køber eksperter bosat i udlandet, fx i Indien, til derfra og for væsentligt lavere lønninger at designe de computerstyrede dele af deres virksomhed. Og som et nyt skud på lavtlønspolitikken har SAS opkøbt Cimber Air, hvor løn og arbejdsforhold er betydeligt ringere end hos SAS. Ved herefter at flytte arbejdskraft fra SAS til Cimber Air vil lønomkostningerne for den nye SAS-koncern falde. Endelig skal nævnes, at mange små og nystartede restaurationer og cafeer i stort omgang (lovligt) anvender meget lavtlønnet østeuropæisk arbejdskraft. Tal har vi dog ikke. 
Hertil kommer, at selv hvor fagforeningerne sikrer, at den udenlandske arbejdskraft aflønnes til danske overenskomster, foretrækker mange danske virksomheder at beskæftige arbejdere fra fx Polen og Rumænien, fordi de danske lønninger er så meget højere, at de udenlandske arbejdere er både flittigere og mere tilbøjelige til at acceptere de øvrige formaliserede og uformelle arbejdsvilkår, end danske arbejdere er (interview med en repræsentant for Dansk Industri, Program 1, 11/11- 2014).

Det er som nævnt en af denne artikels formål at pege på, at der for virksomhederne er andre veje til at opnå konkurrencemæssige fordele end ved at satse på lave lønninger, og at en af disse veje er at benytte sig af de fordele, som et velkonstrueret og velfungerende flexicurity-system kunne give. Vi skal nedenfor komme med en række forslag til, hvordan 'security'-delen af et sådant system kunne se ud, men skal her og nu begrænse os til at pege på, hvordan fleksibilitetsdelen kunne udnyttes langt bedre.

En adgang til efter behov og uden omkostninger at hyre og fyre arbejdskraften (numerisk fleksibilitet) kombineret med at kunne udnytte arbejdskraftens evner ligeledes efter behov (funktionel fleksibilitet) kan ved organisatoriske omstillinger og teknologiske innovationer fremme mange virksomheders produktivitet og herigennem en øget konkurrenceevne og indtjening.

Vælger fagforeningerne og de politiske partier en vej for den økonomiske politiks udformning, der frem for løntilbageholdenhed indebærer en mere aktiv og aggressiv lønpolitik, tvinger de højere lønninger virksomhederne til at foretage rationaliseringer i form af øgede investeringer og/eller organisatoriske effektiviseringer af vare- og tjenestefremstillingen. Stigende lønninger presser produktiviteten og investeringerne frem (den såkaldte 'Ricardo'-effekt). Og for den arbejdskraft, der eventuelt overflødig- gøres og ikke umiddelbart vil kunne finde ny beskæftigelse, vil der stadig - inden for rammerne af en ny udformning af flexicuritymodellen, jf. nedenfor - være rimelige forsørgelsesmuligheder, samtidig med at det er statens opgave at sørge for effektiv arbejdsformidling, videreuddannelse og omskolingstilbud. Hertil kommer en 'pakke' af offentlige jobs for arbejdsløse, der under vekslende konjunkturer ikke kan beskæftiges i ordinære jobs i den private eller offentlige sektor, jf. nedenfor.

I den udstrækning, hvor ny teknologi, ændret organisering og produktivitet vil være ledsaget af kvalitative forbedringer af de fremstillede produkter eller servicer, vil der være åbnet muligheder for virksomhederne til at sælge til højere priser. En kortlægning af det danske bytteforhold - forholdet mellem eksportpriser og importpriser - viser, at der inden for især det seneste årti er sket en ganske betydelig forbedring (Danmarks Statistiks løbende opgørelser; Arbejderbevægelsens Erhvervsråd 2011; LO 2012) og, at denne bytteforholdsforbedring har ydet et årligt bidrag til væksten i bruttofaktorindkomsten set i forhold til væksten i bruttonationalproduktet på 0,5 \% (i bruttonationalproduktet indgår ikke alle bytteforholdsforbedringer i opgørelserne, jf. Arbejderbevægelsens Erhvervsråd (2011)). Når Danmarks eksportpriser således vokser hastigere end vore importpriser (stigende bytteforhold), vil vi kunne importere en større mængde varer og tjenester for en given mængde eksport. Et stigende bytteforhold øger dermed Danmarks købekraft og derigennem vor velstand.

Højere lønninger vil presse virksomhederne til at blive mere produktive og derved fremme den velfærdsudvikling, som Produktivitetskommissionen (2014) peger på, at Danmark går glip af ved en alt for lav produktivitet. Arbejdskraftens omstilling, kunnen og evner skal efter kommissionens 
opfattelse tilpasses fleksibilitetskravene i den nye vidensbaserede og globaliserede økonomi.

Heroverfor fremhæver vi, at et relativt højt lønniveau vil være et stærkt incitament for virksomhederne til gennem rationaliseringer, kapitalinvesteringer og ændrede organisationsformer at sikre innovation og dynamik. Det kunne ved første øjekast mere ligne en komplementaritet end et alternativ. Snarere er der dog tale om en væsentlig forskellig opfattelse af statens rolle, idet vi gør os til talsmænd for en flexicuritymodel, som både er vækstfremmende og skaber en god sikring af lønmodtagerne ved arbejdsløshed. Vi argumenterer for en velfærdsstat, som lægger vægt både på ordentlige lønninger, gode beskæftigelsesmuligheder og (næsten) en afskaffelse af arbejdsløshed. Det sidste sker ved, at de personer, som under de eksisterende konjunkturer ikke kan finde arbejde i ordinære jobs, tilbydes ansættelse via en jobpulje - en pulje af jobs med en bred vifte af arbejdsopgaver og med et aflønningsniveau svarende til overenskomsternes mindsteløn, jf. nedenfor.

\section{Et alternativ}

Når vi argumenterer for, at den svenske model, Folkhemsmodellen eller Rehn-Meidnermodellen, er et alternativ til de paradigmer og modeller, der er dominerende i dag, er det først og fremmest fordi dens erklærede målsætning er fuld beskæftigelse og lighed (Hedborg \& Meidner 1984). I dag er den vigtigste økonomisk-politiske målsætning lav inflation, som kan opnås gennem en effektiv konkurrence - på arbejdsmarkedet en effektiv konkurrence mellem udbyderne af arbejdskraft og derfor tilstedeværelsen af arbejdsløshed af et vist omfang. Efter Rehn-Meidnermodellen skal inflationen holdes i ave gennem samordnede og ansvarsbevidste aftaler mellem repræsentanter for kapital og arbejde, altså en modificeret konkurrencemodel, hvor konkurrencen på markedet er den bagvedliggende faktor for det forhandlingsresultat, der opnås.

De tre væsentligste elementer i RehnMeidnermodellen er solidarisk lønpolitik, aktiv arbejdsmarkedspolitik og en stram finanspolitik. Den solidariske lønpolitik skal sikre en retfærdig og lige fordeling af indkomsterne. Når indkomsterne (lønnen) gøres lige og til dels uafhængige af den enkelte virksomheds økonomiske situation, vil nogle virksomheder ikke kunne overleve. De virksomheder, der ikke investerer i nye maskiner til forøgelse af produktiviteten, vil ikke kunne klare sig. Den solidariske lønpolitik skal altså anvendes til at presse virksomhederne til at konkurrere på produktiviteten og ikke på lønhøjden. Konkurrencefordelen for den enkelte virksomhed opnås ikke gennem relative lønreduktioner, men gennem investeringer.

De virksomheder, der kommer til at lukke, skal ikke subventioneres "hverken af staten eller af fagforeningerne" (Elvander 1988), men de arbejdere, der mister deres arbejde, skal have en rimelig kompensation og tilbydes andet arbejde, omskoling eller uddannelse, således at de kan finde beskæftigelse andetsteds. Denne såkaldte 'aktive arbejdsmarkedspolitik' er den anden hjørnesten i Rehn-Meidnermodellen.

Det tredje element, lav inflation gennem en restriktiv finanspolitik, skal sikre, at lønkravene fra fagforeningerne holdes i ave, og at den nationale økonomi dermed forbliver konkurrencedygtig. Denne svenske model blev lagt i graven i løbet af 1980'erne, hvor den svenske økonomi krakelerede. Først og fremmest fordi kapitalbevægelserne blev frigjort, og svensk kapital simpelthen flyttede til udlandet. Skal en tilsvarende model etableres i dag, må det ske i hele EU, hvilket kræver en kontrol og begrænsning af eksterne kapitalbevægelser. 


\section{Skitse til et nyt arbejdsløshedssystem}

Det kapitalistiske system har altid anvendt arbejdsløshed til at tilpasse samfundsøkonomien. Arbejdsløshed skal disciplinere lønmodtagerne til at acceptere lavere løn og ringere arbejdsforhold. Men arbejdsløshed er samtidig et spild af ressourcer, og set i et samlet samfundsøkonomisk perspektiv er arbejdsløshed uøkonomisk. Samtidig skaber arbejdsløshed økonomisk og social usikkerhed og dermed manglende efterspørgsel, som forstærker arbejdsløsheden. Ikke mindst skaber arbejdsløshed mindreværd og psykiske problemer, ligesom det får nogle mennesker til at mistænke de arbejdsløse for at være dovne. Det handler derfor om at undgå arbejdsløshed i samfundet, sådan som Rehn-Meidnermodellen blandt andet har som målsætning.

En målsætning om fuld beskæftigelse er dog ikke ensbetydende med, at arbejdsløshed kan undgås. Det er derfor vigtigt med et arbejdsløshedssystem, der minimerer arbejdsløsheden og samtidigt forbedrer fleksibiliteten. Midlerne er tilbud og positive incitamenter, i modsætning til tvang og negative konsekvenser. Det formuleres i følgende otte punkter.

1. Der etableres en arbejdsmarkedsrådgivning for alle - både arbejdsløse, uddannelsessøgende og beskæftigede - som er frit tilgængelig og gratis. Rådgivningen skal have fokus på fremtidige beskæftigelsesmuligheder - blandt andet gennem omskoling og videreuddannelse. Fagforeningerne og arbejdsgiverforeningerne deltager i rådgivningen. Arbejdsformidling og jobcentre afskaffes og erstattes af en statslig styret rådgivning, som er opdelt på regionsniveau.

2. Uddannelsesindsatsen opprioriteres, og der etableres eventuelt nye former for uddannelse, som tilgodeser uddannelsesmæssigt svage grupper. Alle virksomheder er forpligtet til at etablere lære- og praktikpladser, og de kompenseres økonomisk for det. Brugerbetaling for efteruddannelse afskaffes.

3. Der oprettes en jobbank med garantijob inden for den offentlige sektor. Garantijobbene skal etableres inden for så en bred vifte af jobområder som overhovedet muligt og omfatter alt fra ufaglærte jobs til administrative og ledende stillinger i det offentlige. Arbejdsopgaverne i garantijobs er således meget forskellige: Bedre bemanding i vuggestuer, børnehaver, fritidshjem, skoleklasser og videregående uddannelser, til alle personalegrupper på hospitaler, socialrådgivning, renovering og udbygning af skoler og andre offentlige institutioner, miljøforbedringer som oprydning af giftgrunde og anlæg af naturparker mv. Både staten og kommunerne er ansvarlige for etablering af garantijob, som de allerede har en vis erfaring med.

4. Garantijob skal være ekstraordinære job, som forhandles med arbejdsmarkedets parter, og de må ikke fortrænge ordinære job i den offentlige sektor. Der er behov for faste normeringer på de fleste arbejdsområder i det offentlige. Garantijob er job med almindelige lønmodtagerrettigheder/ -pligter. Garantijob aflønnes med en særlig løn, som i princippet svarer til mindstelønnen på fagets område eller områdets begyndelsesløn.

5. Ligesom i det nuværende fleksjobsystem tilbydes fleksjob til alle personer med funktionsnedsættelser, men systemet udvides til også at omfatte personer med varige sociale og personlige problemer. Der etableres flere socialøkonomiske arbejdspladser, som skal beskæftige personer med forskellige typer af psykiske og sociale problemer. 
6. Kontingent til a-kasse er obligatorisk for alle lønmodtagere, som er tilknyttet arbejdsmarkedet, og det opkræves ved at forhøje det eksisterende arbejdsmarkedsbidrag.

7. Ved arbejdsløshed kan man højst modtage dagpenge i tre måneder, og perioden er til rådighed for den ledige til selv at skaffe sig et job eller påbegynde en videreuddannelse eller omskoling, støttet af den under punkt 1 omtalte arbejdsmarkedsrådgivning. Herefter er man sikret enten et garantijob eller et uddannelsestilbud.

8. Der etableres en garanteret mindsteindkomst (GMI), som er en mulighed for dem, der fravælger et garantijob. Størrelsen fastlægges politisk, men må ikke ligge under den nuværende fattigdomsgrænse. Beløbet tildeles hver enkelt person, og der tages ikke hensyn til ægtefælles/samlevers forhold. Der stilles ikke arbejdskrav og kontanthjælpen afskaffes.

Fordelene ved systemet er, at arbejdsløshed minimeres - bortset fra de tre måneders søgeperiode efter nyt arbejde eller uddannelsestilbud. Skitsen indeholder ikke tvang og altså heller ikke (tvangs)aktivering. Desuden reduceres det samfundsmæssige 'spild', fordi alle udfører arbejde eller er under uddannelse, ligesom de arbejdsløse undgår mistænkeliggørelse for dovenskab. Fagbevægelsen skal have en central rolle i rådgivningsarbejdet og i udvikling af garantijob og efteruddannelser. Jobcentrene i kommunerne nedlægges. Arbejdssøgning og arbejdsformidling bliver en del af rådgivningscentrenes opgaver, jf. punkt 1 .

De økonomiske konsekvenser af systemet er vanskelige at forudse. Det afhænger blandt andet af, hvor mange der vil erstatte dagpenge med garantijob eller uddannelse. Man kan beregne ekstraudgiften pr. person pr. år til cirka 17.000 kroner, hvis garantijob erstatter dagpenge. Derimod er ekstraudgif- ten ca. 47.000 kroner, hvis en kontanthjælpsforsørger får et garantijob, og ekstraudgiften er ca. 74.000 kroner, hvis det er en ikkeforsørger på kontanthjælp. Det økonomiske incitament til at tage et garantijob er altså størst for kontanthjælpsmodtagere - især ikke-forsørgerne, som opnår 6.000 kroner mere pr. måned. En dagpengemodtager får kun 1.500 kroner pr. måned ud af et garantijob.

I vort forslag fastsættes den garanterede mindsteindkomst (GMI) politisk, men må ikke ligge under den nuværende fattigdomsgrænse. Den danske fattigdomsgrænse svarer til 103.200 kroner i disponibel indkomst for en enlig i 2013-priser. Hvis man omregner det til et bruttobeløb, svarer det til en kontanthjælp på ca. 135.000 kroner. Det er lidt mere, end en ikke-forsørger på kontanthjælp får i dag, og det svarer til en lønmodtager, der tjener 140.000 kroner om året (som betaler a-kasse og fagforening). Det svarer til en timeløn på knap 85 kroner i timen ved fuldtidsarbejde.

\section{Opsummering og perspektiver}

Vi er opmærksomme på, at en sådan model, som her præsenteres, vil møde en del hovedrysten i en tid, hvor liberalisme, markedsstyring og konkurrence er det herskende paradigme. Omvendt vil modellen kunne blive kritiseret for at være tilpasset det kapitalistiske system og være alt for konform. Eksempelvis er vi selv utilfredse med, at garantijobbene indeholder et element af et Barbejdsmarked og i øvrigt også risiko for, at den offentlige sektor (kommunerne) vil udnytte systemet til at erstatte ordinære jobs med garantijobs. Men vi har alligevel valgt denne løsning, selvom det ville være bedst, at garantijobbene var helt ordinære ansættelser.

Udgangspunktet for vores artikel er, at der i de seneste årtier har været et 'ræs mod bunden', når det handler om lønninger 
og arbejdsforhold. Den højt berømmede flexicuritymodel er blevet til en død sild, og utrygheden på arbejdsmarkedet er stigende. Globalisering og liberalisering af arbejdsmarkedet truer vores velfærd. Men det behøver ikke være tilfældet.

Vi foreslår i stedet at styrke trygheden på arbejdsmarkedet og ændre flexicuritymodellen. En mulighed er at gå tilbage til den svenske model, Folkhemsmodellen med målsætningerne om fuld beskæftigelse og lighed. I stedet for blind konkurrence skal der indgås ansvarsbevidste aftaler mellem repræsentanter for kapital og arbejde - altså en modificeret konkurrencemodel. Virksomhederne skal konkurrere på produkti- viteten og ikke på lønhøjden, og konkurrencefordelen for den enkelte virksomhed opnås ikke gennem relative lønreduktioner, men gennem investeringer.

Lønmodtagerne skal ikke presses eller stresses, men i stedet motiveres til fleksibilitet og efteruddannelse. De skal føle tryghed ved at tilpasse sig nye forhold, som kan fremme produktiviteten, og de skal ikke presses af arbejdsløshed og ringeagt, men tilbydes meningsfuld beskæftigelse og uddannelse i stedet for eksklusion og lediggang.

Arbejdsløsheden skyldes ikke den enkeltes dispositioner og manglende incitamenter, men er samfundsskabt.

\section{RefERENCER}

AE Rådet (2013): Danmark slår Sverige på industrieksport.

Arbejderbevægelsens Erhvervsråd (2011): Dansk velstand vokser markant mere end vi tror, Arbejderbevægelsens Erhvervsråd.

Bauman, Z. (2007): Consuming Life, Cambridge, Polity Press.

Beskæftigelsesministeriet (2007): The Danish Flexicurity model, http://bm.dk/ (findes ikke mere på webadressen).

Danmarks Statistik: Bytteforholdet 1959-2013, Danmarks Statistik, løbende opgørelser.

Elvander, N. (1988): Den svenske modellen, Stockholm, Allmena Förlaget.

Hansen, H. (2007): Flexicurity med svagheder, København, CASA.

Hedborg, A. \& R. Meidner (1984): Folkhemsmodellen, Borås, Rabén \& Sjögren.
Larsson, A. (1998): Social Policy and Economic Performance, i D. Foden \& P. Morris (red.):

The Search for Equity, London, 24-41.

LO (2006): Dagpengesystemet. En analyse af dagpengesystemets doekning, København, LO.

LO (2012): Dansk eksport, produktivitet og voekst sandsynligvis undervurderet, Arbejdspapir af 31. August 2012, København, LO.

Madsen, P.K. (2011): Flexicurity i modvind - en analyse af den danske flexicurity-model under den økonomiske krise, i Tidsskrift for Arbejdsliv, 13, 4, 7-20.

Møller, I. H. m.fl. (2008): Aktivering - disciplinering til arbejde, København, CASA og LEO.

Produktivitetskommissionen (2014): Slutrapport. Det handler om velstand og velfoerd, København.

Weber, M. (1920): Die Protestantische Ethik und der Geist des Kapitalismus, Thübingen.

Henning Hansen, forsker, CASA・ e-mail: heh@casa-analyse.dk

Jens Lind, professor, Aalborg Universitet• e-mail: jlind@socsci.aau.dk

Iver Hornemann Møller, professor, Linnéuniversitetet • e-mail: iverhm@hotmail.com 